\title{
Historizing the concept of family
}

\section{Historicizando o conceito de família}

\section{Historizar el concepto de familia}

\author{
Cristiane De Assis Lucifora ${ }^{1}$ (D) Luci Regina Muzzeti $^{1}$ (D) Fabio Tadeu Reina $^{1}$ iD \\ ${ }^{1}$ São Paulo State University, Araraquara, São Paulo, Brazil. \\ Corresponding author: \\ Cristiane De Assis Lucifora \\ Email: mailto:cristiane.lucifora@gmail.com
}

How to cite: Lucifora, C. A., Muzzeti, L. R., \& Reina, F. T. (2021). Historizing the concept of family. Revista Tempos e Espaços em Educação, 14(33), e16795. http://dx.doi.org/10.20952/revtee.v14i33.16795

\begin{abstract}
Nowadays, we observe that the concept of family continues to change for/in society. The birth of the feeling of childhood is problematized as one of the factors present in the formation of the modern concept of family, since it considers the space that the child starts to occupy in society. Therefore, this work reflects on how the concept of family flourished, manifesting itself as arbitrary. The importance of historical penetration is pointed out as a way to deconstruct this conceptual rooting that, in a natural way, transits through the various fields, excluding family arrangements that differ from the assumed norm, known as patriarchal. It is research with a qualitative approach of bibliographic character with a theoretical framework on the proposed theme. The analysis is based on the praxiology of Bourdieu. The results showed that there is a need to include in the formation of students and teachers questions about the various concepts of family and their implications in school practice. Thus, it is considered that there is a need to think and act on the permeated concepts of family, so that a new paradigm, this time more marked by tolerance, can emerge so that in fact all family formations can enjoy relationships that exist in this milieu.
\end{abstract}

Keywords: Child and childhood feeling. Families. Family arrangements.

\section{RESUMO}

Na contemporaneidade observamos que o conceito de família continua mudando para/na sociedade. O nascimento do sentimento de infância é problematizado como um dos fatores presentes na formação do conceito moderno de família por levar em consideração o espaço que a criança passa a ocupar na sociedade. Diante disso, este trabalho reflete sobre como o conceito de família floresceu manifestando-se como arbitrário. A importância do adentramento histórico é apontado como um caminho para a desconstrução deste enraizamento conceitual que de forma naturalizada transita pelos diversos campos excluindo os arranjos familiares que diferem da assumida norma, conhecida como patriarcal. Trata-se de uma pesquisa de abordagem qualitativa 
de caráter bibliográfico com arcabouço teórico acerca do tema proposto. A análise é realizada a partir da praxilogia de Bourdieu. Os resultados apontaram que há necessidade de inserir na formação de alunos e professores as questões sobre os diversos conceitos de família e suas implicações na prática escolar. Considera-se assim, que existe uma necessidade em se pensar e agir sobe os conceitos perpassados de família, para que se possa ver um novo paradigma, dessa vez mais marcado pela tolerância, surgir para que de fato todas as formações familiares possam gozar das relações que existem nesse meio.

Palavras-chave: Arranjos familiares. Famílias. Sentimento de criança e infância.

\section{RESUMEN}

En la actualidad, observamos que el concepto de familia sigue cambiando para / en la sociedad. El nacimiento del sentimiento de infancia se problematiza como uno de los factores presentes en la formación del concepto moderno de familia, ya que toma en cuenta el espacio que el niño comienza a ocupar en la sociedad. Por tanto, este trabajo reflexiona sobre cómo floreció el concepto de familia, manifestándose como arbitrario. Se señala la importancia de la penetración histórica como una forma de deconstruir este arraigo conceptual que, de manera natural, transita por los diversos campos, excluyendo los arreglos familiares que difieren de la norma asumida, conocida como patriarcal. Se trata de una investigación con enfoque cualitativo de carácter bibliográfico con un marco teórico sobre el tema propuesto. El análisis se realiza desde la praxiología de Bourdieu. Los resultados mostraron que es necesario incluir en la formación de estudiantes y docentes preguntas sobre los distintos conceptos de familia y sus implicaciones en la práctica escolar. Así, se considera que existe la necesidad de pensar y actuar sobre los conceptos permeados de familia, para que pueda surgir un nuevo paradigma, esta vez más marcado por la tolerancia, para que de hecho todas las formaciones familiares puedan disfrutar de las relaciones que existen en este país. medio.

Palabras clave: Arreglos familiares. Familias. Sensación de niño y niñez.

\section{INTRODUCTION}

This article with a qualitative approach, coined by a bibliographical study, constitutes a section of a doctoral research on the concept of family today (situating the 21st century) that undergoes continuous changes, including in the legal sphere that gives breadth of social acceptance to arrangements that differ from the assumed norm. For a long time, the idea prevailed that the "normal" family arrangement, also known as patriarchal, would be one with heterosexual molds in which the woman dreams and is dedicated to motherhood and the man assumes the role of family provider.

The work is important for dealing with an issue that deserves much reflection due to the ideological clash present in society about which types of families are valued and respected. Understanding the historical-cultural constructions on the concept of family that predominated for a long time, allows the understanding that nothing is static and that we can increasingly move towards more empathic relationships with respect to the other who is heterogeneous, who differs from us by its uniqueness.

Many were the transformations that society went through, including changes in gender and sexuality relationships, which brought the need for change to/in/between family relationships; new/other arrangements were expanded and even viewed as capable of existing with respect and dignity. It is in this scenario that this article is based on authors such as Bourdieu (2011 and 2018), Perez (2010) and Singly (2007), who bring a rich bibliography on how the notion of family manifested itself, was and is still much discussed throughout history and the social implications that gave theoretical support to this article.

History presents us with the possibility of realizing how transitory certain postures and concepts are in front of what is considered and accepted as normal, possible and dignified within 
the cultural and social fabric that is established. Historical studies allow us, when we open ourselves to study and understand them, to realize that human relationships are not static and that we must divest ourselves of our predetermined concepts in order to really know history, since much of what we experience in our daily lives is the result of many historical, cultural and social transformations and even so it is not unanimous in the historical time in which we find ourselves.

Many behaviors are socially assumed as inherent and belonging since the origin of civilization, being transmitted in family relationships and institutions in which the subjects are inserted. A whole range of learning on how to behave and live in society are put into practice in social relationships manifested within the culture, in the relationship with others.

Gender relations are one of the phenomena present in these types of learning put into practice by various institutions, including the family. By bringing reflections on family configurations, it is necessary to also discuss the weight of gender in these configurations.

In this context, it is necessary to signify gender, since such a social marker of difference is present in family relationships and in the practices that move the subjects and the relationships between them in the social sphere. Gender is conceptualized by Beleli (2010) as a label that differentiates socially and focuses on various relationships such as affective, leisure, work, among others, and which often acts by devaluing some category of human beings based on the way they behave and position themselves based on standards of how men and women should be, behave, interact with each other in society.

The article points out some of the transformations in the relationships between men and women, throughout history, which have expanded the way in which families are organized, from the number of members to the way in which interactions take place.

The question that this work raises is: how have the alterations in gender relations changed the way in which families are organized and to what extent do such alterations effectively affect all categories of subjects? The concept of family has gone through changes historically and understand how society currently (21st century) deals with new/other concepts, becoming important and relevant for a society that seeks greater plurality in relationships with a focus on respect for differences.

Thus, this study seeks to bring a reflection on the concept of family throughout human history and how this institution has changed along with society and also changed society as it changed, thus trying to shed light on a discussion of a more inclusive concept of family, which accepts diversity better, adapting itself, once again, to the times and ways of modern living. Along this reflexive path, we also point out the resistances and barriers that the adoption of this family concept still faces in society, both from the point of view of governments and the subjects themselves that make up the still dominant nuclear family model.

The text is structured as follows: in the introduction, the objective, the theoretical and methodological contribution of this study are woven; in the following chapters, the historical and thought lines about the concepts of family will be placed, as this institution has changed over time, also exposing the barriers that, again, are imposed due to a change in this institution that we present when confronting the family with the contemporary technological world and its diversity; finally, we conclude with our considerations and notes on the main points discussed in the article.

\section{HISTORIZING THE CONCEPT OF FAMILY}

Noronha and Parron (2020, p. 3, our translation) point out that "The origin of the family is directly linked to the history of civilization, since it emerged as a natural phenomenon, the result of the human being's need to establish affective relationships in a stable manner". These authors clarify that initially the family was assumed from an economic point of view and for reproduction purposes, to later assume a perspective centered on affectivity that changes the paradigm of these 
relationships from something arising from the need to something more malleable, possible to acquire new formats and meanings.

Bourdieu (2011, p. 120, our translation) points out that the family is an institutional, ritual and technical product that aims to permanently fix feelings in each member of the constituted unit to ensure the integration that is a condition for the permanence of this unit, and such

[...] inaugural acts of creation (imposition of the family name, marriage, etc.) find their logical extension in the innumerable acts of reaffirmation and reinforcement that aim to produce, through a kind of continued creation, the obligatory affections and affective obligations of family feeling (conjugal love, paternal and maternal love, filial love, fraternal love, etc.).

The name attributes constancy in all social fields that agents move through, being a socially instituted form. Its imposition is arbitrarily carried out by institutional rites not attesting to the identity of the personality. The surname as a possibility of continuity for the family for a long time acted as a class badge, in certain contexts, even today, it acts directly as a socially recognized hierarchical structure.

Bourdieu (2011) points out that the dominant definition of family rests on concepts such as home and domestic unit that are part of social reality. For Bourdieu (2011, p. 124, our translation) "According to this definition, the family is a set of related individuals, linked together by alliance, marriage, parentage, or, exceptionally, by adoption (kinship), living under the same roof (cohabitation)".

The explanation put forward by Bourdieu (2011) about what would be a family is anchored in already modern parameters, which were historically and socially strengthened around the 17th century, and which were motivated by new types of relationships regarding marriage and the feeling of child/childhood. Social changes that strengthened the search for privacy and greater care for children, their hygiene and education.

Bourdieu (2011, p. 127, authors' highlights, our translation) argues that:

In all uses of classificatory concepts, such as the family, we make at the same time a description and a prescription that does not appear as such because it is (almost) universally accepted, and admitted as given, we tacitly admit that the reality to which we assign the name of family, and which we put in the category of true families, is a real family.

From what the author presents, it is understood that family relationships act as common principles of vision and division, which are inculcated in us by various institutions in an intense work of socialization. This construction principle is one of the elements mentioned by the author as constitutive of our habitus - a concept that identifies sets of actions, habits, practices, choices, etc. which can act as unifiers or separators of people, generating splits in the societal fabric - being inculcated as a mental structure explored by socialization, but at the same time being an individual and collective process, it acts as common sense, the doxa accepted by all.

Within this consensus and social acceptance of things taken as truths, therefore legitimized, there is also a whole social pressure to meet the demands of certain roles (assumed by the man, assumed by the woman) and which, when not met, elevate the agents to be seen as incomplete, unfinished and even mutilated. The cultural constructions that reinforce characteristics such as being from the male or female universe are also present in family relationships, delimiting the possible spaces to be occupied, social demands on how to be, exist and act.

Biroli (2014, p. 16, our translation):

The sexual division of labor, making men distinctly responsible for material provision and women for domestic work - unpaid and invisible as productive work - would be justified by 
ideals of motherhood and domesticity that were carried out in a very localized way. In practice, this division was within the reach of few households because it depends on the husband's remuneration being equivalent to a family salary. The provider man, on the one hand, and the housewife, on the other, are characters who have a well-defined social class, position in labor relations and color. The ideal family, which served and to some extent continues to serve as a reference for judging distortions and deviations, and defining public policies, has always been a chimera for most of the population.

Women still today (21st century) see themselves required to be mothers and being mothers who correspond to the maternal model of care, who are wives dedicated to domestic tasks and are concerned with their physical appearance to meet the socially imposed ideals of beauty. Men who are virile, financial providers of the home, even though their wives also work, are not charged in relation to the care of their children regarding hygiene and education.

Scavone (1995, p. 1, our translation), highlights:

Between the reduced model of motherhood with an increasing variety of types of mothers (housewives, head-of-household mothers, "independently produced" mothers, "egalitarian couples") and the various solutions found for child care (schools with full-time, public day care centers, nannies, specialized schools, neighbors who look after, children left in their own care, solicitous grandparents), motherhood is changing, following both demographic pressures - from birth or control - and different feminist pressures and the desires of each woman.

The changes generated by gender and sexuality transformations impacted social relations, reflecting in different family configurations as a consequence of social and cultural transformations. The traditional patriarchal model of the family that for a long time was taken as natural and eternally existent was also built at a given historical moment and served the interests of that social context.

Understanding how the concept of family was historically constituted is very important to understand why some characteristics are so resistant to change and the impacts that the denial of this change triggers in society.

Bourdieu (2011, p. 128, our translation) points out:

Thus, the family as an objective social category (structuring structure) is the foundation of the family as a subjective social category (structured structure), a mental category that is the basis of thousands of representations and actions (marriages, for example) that contribute to reproducing the category objective social. This circle of reproduction of the social order. The almost perfect agreement that is established between the objective categories founds an experience of the world as evident, taken for granted. Nothing seems more natural than the family: this arbitrary social construction seems to be situated at the pole of the natural and the universal.

In the same direction, Dessen and Polonia (2005, p. 22, our translation) state that:

As the first mediator between man and culture, the family constitutes the dynamic unit of affective, social and cognitive relationships that are immersed in the material, historical and cultural conditions of a given social group. It is the matrix of human learning, with its own meanings and cultural practices that generate models of interpersonal relationships and individual and collective construction.

Regarding what is considered family grouping, the historical study allows us to perceive how many transformations this institution has undergone and how this continues to be influenced by 
changes present within society and culture (stable unions without marriage, families that include more than one partner, choice families, among others).

In the Brazilian context, it is possible to identify the family constitution as a result of the miscegenation of ethnic groups and cultures having a great systematized and repressive control established by the Catholic Church and which defined the route of marriage as necessary for the family base. We can point out in Brazil a triad constituted by the indigenous, European and African ethnic groups, in which a great process of acculturation through evangelization was put into practice since the colonization process.

Biroli (2014, p. 24, our translation):

Patterns in family arrangements in Brazil have changed a lot in recent decades. When comparing the Brazil of today to the mid-twentieth century, people marry later, especially women, and separate more often. They have, on average, fewer children than before and the children, in an increasing number, grow up in domestic environments that are very far from the nuclear family pattern - that of the families in television commercials, formed by father, mother, a son and a daughter, all smiling and together during meals. The position of women and men has also changed, both in social relations in a broader sense and in the domestic sphere. More women are heads of households, which means that more women are the main breadwinners and more mothers are raising their children alone.

By revisiting historical studies on family configurations, feelings of child and childhood, school institutions, socially accepted affective relationships that are key theoretical tools for this research, we find in the history of civilization, postures that were usual in a given context and that in our eyes they escape the sphere of normal and acceptable.

According to Laraia (1999, p. 70, our translation) "The way of seeing the world, the moral and evaluative appreciations, the different social behaviors and even the body postures are thus products of a cultural heritage, that is, the result of the operation of a certain culture". While there are some common features regardless of culture, there are also manifestations that differ and distinguish one from another.

Bourdieu (2011) points out that the family is the result of an intense institutional work, being ritual and technical, sustaining in a lasting way adequate feelings to ensure the integration aimed at the maintenance and persistence of this unit.

For both Singly (2010) and Ariès (1981), controlling the number of children also involves the birth of the feeling of childhood and this "New place that the child occupies". The birth of the feeling of childhood and child comes full of care and specificities that need to be put into practice and that must also count on something important, which is the family structure. It is up to the family to take care of the being who sees himself as helpless and fragile and to pass on values that are considered necessary.

The change in what the child means in/for the family comes as one of the axes of several transformations that the family will go through. This understanding of the child is put forward by Ariès (1981) when explaining how the feeling of childhood was born, after a long journey with several transformations occurring in many social, cultural and economic spheres, and problematizes that this concept did not occur at the same time at all the contexts, first because the child, as the author discusses, is considered and educated as an adult. The child was gradually recognized and made up of specificities, care and protection were needed for them to develop fully and fully.

For Ariès (1981, p. 25, our translation):

Thus, although demographic conditions did not change much from the 13th to the 17th century, although infant mortality remained at a very high level, a new sensitivity attributed to these fragile and endangered beings, a particularity that no one bothered to acknowledge before: it 
was as if the common conscience only then discovered that the child's soul was also immortal. It is true that this importance given to the child's personality was linked to a deeper christianization of customs.

This reinforces the idea of childhood fragility and the need for education united with the family, acting in its development, moral and intellectual formation. It is important to point out that the feeling of childhood benefited the boys first, making the girls remain in the traditional molds, still uncertain among adults and being a characteristic that advanced throughout history. More encouragement and time were given to the boys so that they could explore their potential.

New paradigms are created, changing all family and societal interactions with children, and issues related to sexuality are now banned and seen as inappropriate for children and as dangerous to tarnish child innocence. Ariès (1981, p. 75, our translation) points out that:

One of the unwritten laws of our contemporary morality, the most imperative and the most respected of all, requires adults to refrain from any allusion, especially joking, of sexual matters in front of children. This feeling was totally foreign to the old society.

The child gained increasingly important status within the family, being conceived as fragile and placing their education as a social priority. There was a concern with indoctrinating and disciplining children, relying on the educational institutions that in their rites or curricula reinforced the teachings that were already consolidated at home, molding again the entire family structure around this new concept of caring for children, with school and psychological institutions being created with a focus on their education, aiming through this to indoctrinate and discipline them.

Ariès (1981, p. 105, our translation) reinforces that:

Everything about children and the family had become a serious matter and worthy of attention. Not only the child's future, but also its sheer presence and existence were worthy of concern the child had assumed a central place within the family.

School and college were established as important for the education and moral construction of children and young people and gradually gained acceptance and social importance. In principle, schools were very different from how we recognize them nowadays, there was no distinction by age group and it was considered normal that the discipline was imposed in an authoritarian way and with corporal punishment. The educational institutions did not have their own architecture and did not follow a curricular grade.

Over time, teaching began to adapt, looking at the learner, according to their age and development for the formation of school classes, and the rigid disciplinary imposition declined, as postulated by Ariès (1981, p. 119, our translation):

\footnotetext{
The relaxation of the old school discipline corresponded to a new orientation of the childhood feeling, which was no longer linked to the feeling of its weakness and no longer recognized the need for its humiliation. It was now a question of awakening in the child the responsibility of the adult, the sense of his dignity. The child was less opposed to the adult (although differed greatly from him in practice) and was prepared for adult life. This preparation was not done all at once, brutally. It required care and steps, a formation. This was the new conception of education, which would triumph in the 19th century.
}

It is only fair that the reflection on the emergence of the feeling of childhood is accompanied by that of family, as both connect and complement each other and generate conceptions and ideologies that are also present today (Ariès, 1981).

Thus, the author reflects: 
The feeling of the family, which thus emerged in the 16th - 17th centuries, is inseparable from the feeling of childhood. The interest in childhood, which we analyzed at the beginning of this book, is but a form, a particular expression of this more general feeling, the feeling of the family (Ariès, 1981, p. 143, our translation).

This recognition of what would be a family, accompanied by the expansion of learning through the school, was concerned with moral rigor and with protecting the innocence of childhood. The school expansion makes modern civilization bear the mark of the formation of children and young people. Politeness, discretion and respect for intimacy were defended. The domestic environment itself changed its structure, with the need for specialization of the rooms for greater preservation of intimacy.

Abramowicz (1994, p. 20, our translation) signal that:

From the 18th century, when a place for childhood was defined, granting it rights and even privileges, the possibility of moving (also among adults), of existing in their differences was taken away from it; children were imprisoned in families and schools. They became the "same", minor, childish and infantilized. Thus, a power present in childhood that scrambles the codes (of writing, of desires), transposes limits and subverts order was somehow reduced. Adult society, the one that claims the right to beat children and give orders to children (an old practice in childhood history), based on this new scrutiny - family and school - ends up demanding from children new attitudes of discipline, of bonds, speech, etc.

The expansion of learning through the school has expanded and the concern of parents that their children have access increased in the various social strata. It is possible to recognize another mark of this new family feeling, which is the concern for equality between children. In the 18th century, treating children of the same family in a different way would be considered an unacceptable injustice.

Ariès (1981, p. 189, authors' highlights, our translation) points out that:

Even at the beginning of the 19th century, a large part of the population, the poorest and most numerous, lived like medieval families, with children away from their parents' homes. The feeling of home, of chez soi, did not exist for them. The feeling of the home is another facet of the feeling of the family. From the 18th century onwards, the feeling of the family has changed very little. It remained the same as we observe in the rural or urban bourgeoisies of the 18th century. On the other hand, it has spread more to other social strata.

The transformations that enabled the construction and recognition of the specificity of childhood and the family universe made the educational system stand out in a degree of importance, being assumed to be of private family interest and by political spheres. Some fields of knowledge such as Psychology, Pediatrics and Pedagogy have increasingly turned to the understanding of children's development, so that their contributions helped to build an attentive look at childhood, identifying it and placing it on a level of social importance.

Singly (2010, p. 17, our translation) points out that "From the end of the 19th century onwards, the family becomes modern, due to the strengthening of individualism and the growing weight of the affective in relationships". Governments are now concerned with circumscribing individualization, which is considered threatening, and in the French context, in which the author is a reference, policies value the institution of marriage, not guaranteeing women all power over their bodies and insisting on female submission, as well as a strict division in what is expected for females and males; marriage as an institution is considered indissoluble.

For Biroli (2014, p. 7, our translation), 
The family defines itself in a set of norms, practices and values that have their place, time and history. It is a social construction that we experience. The norms and actions that are defined within the State, the production relations and the forms of remuneration and control of work, the scope of sexuality and affections, the representations of the social roles of women and men, childhood and relationships between adults and children, as well as the delimitation of what is personal and private by everyday practices, discourses and legal norms, affect relationships in domestic life and shape what we recognize as family.

Based on what Biroli (2014) enunciates, it is essential to discuss the characteristics and meanings that accompany what we can recognize as the feeling of family, so that in this way we can later advance to the understanding of what family represents in contemporaneity. According to Singly (2010, p. 12, authors' highlights, our translation): "The modern family is progressively built as a private 'space' in which family members mainly value the fact of being together and sharing an intimacy, attentive to qualities of their relationships".

\section{CONTEMPORARY FAMILY: NEW/OTHER CONSTRUCTIONS?}

The path taken for contemporary family construction starts from an isolation of this institution from society, an appreciation of the private and the need for a separation between these two entities, in addition to the construction of an investment by the family in the child beyond care only, this is demonstrated in the various institutions and disciplines that arise for/to understand and educate the child.

For Ariès (1981, p. 164, our translation):

The progress of family feeling follows the progress of private life, of domestic intimacy. The family feeling does not develop when the house is too open to the outside: it requires a modicum of secrecy. For a long time, the conditions of daily life did not allow for this necessary entrenchment of the family, far from the outside world.

About this, Ariès (1981), reinforces that in the eighteenth century, the family began to keep society at a distance, confining the family in a limited space, enjoying an increasingly private life, which prioritized the relationships between parents and children.

In the process of transition from one type of family to another, there is a transformation of the economic heritage in relation to school capital. From the 19th century onwards, the search for diplomas and a family investment by parents so that their children can achieve professional success increased; parents try to provide good foundation conditions for their children to get the best jobs. Even though children are no longer treated as adults, there is a construction of a "child investment" on the part of parents, shaped by society's demands, demanding high education for children and expanding each time, keeping up with the pace of change that would mark that century, schooling becomes the basis of this process, as well as, in principle, a factor of class distinction.

The expansion and access to secondary education in France around the 1960s boosted the search for diplomas and created the opportunity for women to have the same level of education as men. Singly (2010) states that urbanization, as well as industrialization, contributed to the creation of the modern family, but it is the wage society, with the welfare state and the strength of schooling that supported the transition to the modern family.

It becomes necessary, then, that we situate ourselves historically, recognizing that the concept of family that currently exists is called contemporary, having characteristics and specificities that diverge from what was assumed to be modern. Singly (2010, p. 9, our translation) discusses this, stating that: "The contemporary family exists less in function of formal criteria than in relation 
to a double requirement: the creation of a framework of life where each one can develop while participating in a common work".

Singly (2010) emphasizes that since 1960, in Europe, there has been a progressive disappearance of the legitimacy of marriage, which is no longer the essential criterion for the formation of a family; children outside and within the regulated union and who have the same rights. The idea that becomes predominant is that of common belonging, so that the uniqueness of each member is maintained. Respect for individuality, within a collective, marks a society that is increasingly plural and that recognizes that following standards is no longer so viable.

The child in contemporary times has a space of great value having recognized its specificities and degree of importance. The family is responsible for its protection regarding health care, food, hygiene, schooling etc. It is the family's responsibility to ensure that all their needs are met. Documents exist that list such needs and child's rights. However, it must be reflected that although there is an effort to achieve these goals, there are many children at risk and vulnerability and, unfortunately, the laws are not able to contemplate.

Historically and socially, children have achieved a higher status in importance and with this, there has been concern about their protection, they become the center of family affection and some interdictions are now considered, such as the prohibition of child labor - as governs the Statute of Children and Adolescents since its publication in the late 1990s (Brasil, 1990) - the extension of their schooling and the search to guarantee their social and legal security. Families decreased in size and sentimentalization increased.

Dessen and Polonia (2005, p. 27, our translation) highlight that:

This involvement occurs in different ways of monitoring the tasks, monitoring their performance, or even in systematic guidance of social behavior and the children's engagement in school activities, carried out on their own initiative or at the school's suggestion.

It is also necessary to bring to the discussion that although we have apparently "evolved" in the acceptance of the diverse subject, of the heterogeneous family, and this will be possible to see regarding the acceptance of different family configurations and affective relationships, there is still resistance to accept some types of family arrangements. The other has the right to be different, as long as his condition of difference does not disrespect anyone, and in this way a range of interdictions assumed as disrespect is opened. These are actions of resistance preventing some subjects from enjoying a life free from prejudice.

Guiddens (2003, p. 67, our translation) "Only a minority lives today in what could be called the standard family of the 1950s - both parents living together with the children born of their marriage, the mother being a full-time housewife and the father providing support". The mass insertion of women in the labor market has changed marital relationships and ways of expressing motherhood. Many family arrangements were formed because of social, cultural and economic transformations.

The weight of inheritance (economic capital) as problematized by Bourdieu (2018) and Singly (2010) was gradually replaced by ties formed by love and sexual attraction, providing a romanticization of love choices that poses as devoid of any kind of interest, being love for love.

Giddens (2003, p. 69, our translation), points:

While statically marriage is still the normal condition, for most people its meaning has changed almost completely. Marriage means that a couple is living in a stable relationship and can actually promote that stability as it involves a public declaration of commitment. However, the marriage is no longer the main defining base of the union. 
It is not possible to establish a universal conceptualization of the family, as stated by Giddens (2003), since history shows us how complex relationships have become, but it is clear that the State still adheres to the idea of a patriarchal family, which configures a challenge to move away from the Catholic ideal, opening up to the recognition of the family seen from the perspective of solidarity and parenting. In 1988, the Brazilian Federal Constitution (Brasil, 1988) introduced legal recognition and protection to different types of family grouping, so that families are incorporated into legislation in a more pluralized, democratic, egalitarian way, respecting different sexual ties.

About this, Kornatzki and Ribeiro (2019, p. 2, our translation), argue that:

The debate on the meaning of family, given the recognition of different family configurations, has raised several discussions in different spheres of Brazilian society. The legal and legislative field, as well as the actions of civil and religious society, have mobilized adverse debates, constituting a struggle composed of two antagonistic sides. On the one hand, groups in favor of expanding the concept of family, on the other, groups against this movement.

These authors point out that it is possible to identify some actions of the legal system regarding the production and regulation of the family, participating in the construction of subjectivities and participating in the expansion of the concept today. The recognition of different family arrangements, legalization of divorce, civil unions between people of the same sex are examples of changes that the legislation has participated in.

It is important to problematize that the power of the State occurs according to Bourdieu (2011, p. 97-98, authors' highlights, our translation):

If the State can exert symbolic violence, it is because it is incarnated both in objectivity, in the form of specific structures and mechanisms, and in "subjectivity" or, if you like, in the minds, in the form of mental structures, of schemes of perception and thinking. Given that it is the result of a process that institutes, at the same time, the social structures and the mental structures adapted to these structures, the instituted institution makes you forget that it results from a long series of institutional acts and presents itself with all natural look.

Capital holders fight for power over the state, over state capital that ensures power over different types of capital and its reproduction also takes place through the school institution, relying on symbolic capital to ensure its concentration and permanence. There is a cultural unification that makes certain impositions legitimate, but as access is not given to everyone on an equal basis, many find themselves restricted in their full humanity.

Bourdieu (2011, p. 116, authors' highlights, our translation) when it comes to the State,

That is, it imposes and inculcates all the fundamental classification principles, according to sex, age, "competence" etc.; and it is the foundation of the symbolic effectiveness of all institutional rites, of all that underlie the family, for example, and also of all those who operate in the functioning of the school system, place of consecration, in which they are instituted, among the elected and the eliminated, lasting, often definitive differences, in the manner of those instituted by the ritual of expansion of the nobility.

This author points out that submission to the established order is constituted by the dialectic between the cognitive structures of collective (phylogenesis) and individual (ontogenesis) history, which is inscribed in the bodies and objective structures of the injunctions of the State, whose power is assured by the cognitive structures through which it is noticed.

Bourdieu (2011, p. 171, authors' highlights, our translation) states that "Symbolic violence is that violence that extorts submissions that are not even perceived as such, based on "collective expectations", on socially inculcated beliefs". There is, as the author reflects, a doxic submission to 
the injunctions of the world, often disguised by social games that manifest themselves with the ontological complicity between mental structures and objective structures present in the social space.

As for this doxic submission, the domestic economy is pointed out by Bourdieu (2011) as an exception, since the family with modern contours was also characterized by the distancing of economic exchange relations. According to the author, this is reflected in a tension since, at the same time as the economic interest in the family base is denied, it links its reach of capital reproduction (Bourdieu, 2011).

Bourdieu (2011) reflects that the Church, especially the Catholic, follows the principles of domestic economy that feed the idea of fraternal exchange maximizing monetary exchanges involving profit. Such reflection is important, as this religious influence on family relationships can be understood, according to Bourdieu (2011, p. 185, our translation), "The truth of the religious enterprise is that it has two truths: the economic truth and the religious truth, which refuses it".

It is a truth that acts in a repressed way. The Church ends up accumulating wealth, but through the "benevolence" of those who participate in it, a kind of bank, but which can never be recognized as such. Religious agents deny the economic scope and assume that the divine service cannot be seen as an office, but rather, performed in gratuitousness and altruism.

According to Bourdieu (2011, p. 188, our translation) "In the religious enterprise, production relations work according to the model of family relationships: treating others as brothers is to put the economic dimension of the relationship in parentheses". Both in the Church and in the family, what is expected is alterity and empathy, dedicating oneself without thinking about receiving something in return, being in a collective dealing with a fraternal way. Family and Church achieve a devotion from their members in very similar ways; they share the idea that their agents are focused on communion, involved in disinterested relationships regarding financial gains, experiencing a fraternity that only seeks the good of the entire group.

\section{CONSTITUTION AND RECOGNITION OF DIFFERENT FAMILY ARRANGEMENTS}

Goldani (1993) points out that the Federal Constitution of 1988 (Brasil, 1988) defines the family as a stable union between a man and a woman or any of the parents and their descendants. Gender equality is placed as a right. The documents demonstrate a transformation in the way of conceiving what would be a family.

According to Noronha (2020), it is possible to list some constitutional principles that guide family law, namely:

- Existence and permanence in marriage, civil or religious;

- Competence of civil law to regulate the celebration and dissolution of marriage;

- Legal equality of spouses;

- Family entities formed by men and women, or by any of the parents and their descendants;

- Possibility of divorce;

- Responsible parenthood;

- Legal equality of children without discrimination;

- Childhood protection;

- It is up to parents to provide assistance to their children.

In article 226, $\S \S 3$ and 4 of the Federal Constitution (Brasil, 1988), family plurality and the Civil Code are recognized, as this provides for assistance to citizens, incorporating family dynamics. Kornatzki and Ribeiro (2019, p. 2, our translation) point out that "Thus, the production of the family in contemporary Brazil takes on a complexification resulting from several factors, one of them being 
the legal and political expansion of the concept, which causes a range of possibilities for recognition of different family arrangements".

For these authors,

In disciplinary society, the legal system operates in disciplining bodies, with the aim of normalizing them. In this sense, the Federal Constitution of 1988, by enabling such an understanding of family, represents a strategy that aims to normalize this instance and, therefore, adapt to the standards of subjects that were on its margins. By stating that certain forms of organization among people come to be recognized as a family, they are framed within norms that are not random, but a product of knowledge and power relations (Kornatzki; Ribeiro, 2019, p. 10, our translation).

When the law starts to consider some types of families and place them in a protective range, does it still disregard several other types of arrangements, despite its expansion, are there still groups that remain on the margins of society?

About this, discusses Biroli (2014, p. 44, our translation) stating:

The boundaries between the legitimate and the illegitimate in family arrangements determine different positions in terms of access to opportunities, resources and social recognition. They impose ways of life and naturalize the inequalities that result from deviations that they themselves establish as such.

The family for the Brazilian Institute of Geography and Statistics - IBGE, Portuguese initials (Demographic Census) is defined as a group of people linked by kinship, domestic dependence or norms of coexistence who live in the same household. Domestic dependence is placed as the situation of subordination of domestic workers and households in relation to the head of the family. Coexistence rule is understood to be compliance with rules established for the coexistence of people who reside in the same household and are not linked by kinship or domestic dependency, a single person living in a private household, a set of a maximum of 5 people who live in a private home, although they are not linked by kinship and/or domestic dependence.

Goldani (1993, p. 88, our translation) states:

As for the concept of family, despite its complexity and discussions about it, the common reference in the speeches is the group of people who live in the same house, maintain kinship and dependency ties, and maintain hierarchical relationships. In other words, there seems to be a hegemonic family model that people's imagination builds.

In this direction, it is possible to understand that in Brazil the still predominant model is the patriarchal one, having the highest authority based on the male figure and also being monogamous. The nuclear family predominates with charges and hierarchies between male and female. Women who carry out solo maternity experience many difficulties, including financial ones, as their condition as mothers is seen as an obstacle to full dedication to the labor market.

The magazine Retratos do IBGE (2017) and the Data from the National Household Sample Survey (PNAD), reveal that since 2015 there has been a decrease in the patriarchal model and that new trends have gained strength. A new type of family is pointed out, gaining space and mixing arrangements in which the spouses already had children from previous relationships and also end up having children in the new union. The number of couples who choose not to have children is also growing, and with the increase in the population's life expectancy, the number of elderly people, mainly women, living alone increases. Homes have decreased in number and mixed with different arrangements.

For Goldani (1993, p. 7, our translation): 
the economic situation changes family dynamics, affecting the economic resources used to maintain well-being and a lifestyle. Thus, precarious living conditions characterize the structures of Brazilian families, that is, their size and internal organization. From this point of view, most families from the lower classes would be permanently threatened by low wages and unemployment, and there is a close relationship between the type of family and the stages of the life cycle of its members.

According to the author, the family, in a recent opinion poll in Brazil, is identified as the most reliable institution, but a large number of people say that the family does not fulfill its role as a provider of affection and financial resources necessary for its maintenance. The family crisis ideology gains strength and is fueled by political and religious leaders.

In this sense, Perez (2010, p. 2, our translation) points out that:

According to research by Perez $(2000,2004)$ it is common to hear that the family group is currently in crisis and even dying out. In fact, what has been happening are changes in the structure and roles of family members, as a result of social changes that, in turn, end up contributing to the existence of different forms of constitution and modalities of family education, denying the historical construction of a unique and ideal family model. By family, currently, we can understand a series of arrangements in the relationships between people linked by bonds of alliance and affinity.

The media, in the mindset of those who believe in the destabilization of the family, is seen as a propagator of the degradation of family relationships by showing different family universes and lifestyles. Social problems such as the increase in crime, especially among minors, are attributed to families seen as dysfunctional.

The power that the media has in the socialization processes experienced in contemporary times cannot be ignored, as it participates in the construction of identities, as well as the family and the school. The flow of information provided by the media is intense, being often inserted in the agents in a fragmented and stereotyped way, reinforcing some cultural prejudices. The culture of mass communication is also responsible for transmitting cultural values and standards.

Goldani (1993, p. 70, our translation) reflects that:

Historically stimulated by society and reinforced by the Catholic Church by the State, until recently, the idea is that there would be a model of the Brazilian family. This family model would be associated with the presence of relatives, a hierarchical and value system in which paternal and male authority over women, monogamy, the inseparability of unions and the legitimacy of offspring would stand out.

Single-parent families headed by women often suffer from the myth of family disorganization; the stigma of the unstructured family and the problem is still strong in a society that claims to be democratic, but which in a veiled way uses strategies to blame those who lack resources for their unequal condition of existence.

\section{RESULTS AND DISCUSSION}

This article discusses the transformations in the concept of family throughout history and some of the characteristics that were socially responsible for the changes. We currently live in a society that is increasingly plural, but at the same time still gives greater visibility to some subjects as being worthy of respect and acceptance.

Gender relations are assumed to be responsible for changes in the relationships between subjects, expanding the range of legally recognized families. The variety of family arrangements has 
always existed, but the non-acceptance of many of them meant that some agents could not enjoy such an important identity mark.

Equality in sexual relations is recognized as one of the essential principles for democratic effectiveness. More equal relations between genders are fundamental in any family organization that values respect and dignity among its members.

Although there are many changes in the meanings of what would be a family, its great importance must be assumed, if respected in its different arrangements, as it means protection, socialization and bond building. Safeguarding respect for different types of arrangements, families are essential places of affection for a more empathetic society.

Gender roles change in family relationships, as well as coexisting distinct family models; one model does not completely overthrow the other, but they intertwine, forming new types of relational dispositions between agents. Reflecting on the changes that gender issues have brought to family relationships is very important in order to understand how the relationship between subjects in their homes has taken place, as well as its implications for society.

Questioning the lack of equality between genders is of paramount importance, as women still lose a lot with the social ties that assign them a hierarchical role that make them inferior. The work overload, as care for the home and children is still naturalized, despite its action in the labor market, is one of the examples by which women still find a glass roof to fully exercise their professional performance.

The belief that the family may be threatened is involved with the idea that a certain family model is standard and, therefore, other family models lack recognition and value. One of the resistance mechanisms for maintaining the model considered as a family pattern is the denial of the existence of other types of family arrangements.

One of the strategies to consider something as being of value is to naturalize it as standard and normal, which on the contrary happens when you want to strengthen the idea that something is out of place and wrong when one of the adopted strategies is the silencing of its existence. The nuclear family model that was defined as modern is still strong, being reinforced in several institutions, including the school, fed with literature, commemorative parties, posters, demands on those responsible, etc.

We bring the problematization about the technological reach impacting on family relationships as it is a challenge that families are currently dealing with. The moments when many families got together to interact have been replaced by the increase in the use of electronics and communication that could strengthen affective bonds have been replaced by an increasing stimulus to individuality.

In addition to the barriers already mentioned, technology also emerges as a means that can complicate or facilitate family relationships. Undeniably, the increasing presence of technology in all spheres of life, including in the family, can be a facilitating or difficulty factor in the relationships that will be woven through or around it, the acceptance of this technology, in which the new generations are born and grow, becomes a factor of split or union, changing the way parents and children can communicate. These new forms of communication, mediated by technology, also constitute yet another factor that acts in the redefinition of relationships within the family, as the influx of information becomes greater and with this the contact and acceptance (or reiteration of the denial) of greater diversity.

The bibliographical repertoire that allowed the construction of this article was of fundamental relevance for structuring the doctoral research that seeks to understand the concept of the participants' family. To analyze what the subjects understood as a family, it was very necessary to understand the way in which meanings about the family universe are socially traced, identifying whether there is a standard concept in their conceptions. 
Through the research presented here, we approach part of how the family is experienced and recognized, how it has changed and still changes, according to history and society itself, prostrating now in front of a society shrouded in technologies and diversity, we can raise the thought of how this new scenario we live in, in which family and subjects that are in them, will affect the reality constituted until now and what developments we can still see within what we know as a family and the conceptions of what it should be.

\section{FINAL CONSIDERATIONS}

By tracing this historical panorama, we realize how much social and cultural experiences are dynamic and change throughout history. The time we find ourselves in is a time marked by the speed at which transformations are constant, we always are led to think about the concepts that we bring with those that are reformulated.

There are several familiar configurations today and the visibility of this dynamic needs to be increasingly questioned. Respect for the different ways in which families are formed and organized needs to be present in all contexts, including the school, which can be seen as a meeting place for difference and which presents a fertile field for diversity to be thought of collectively and considering the singularities of each and every one.

Gender and sexual relations need to be reflected within family dynamics so that naturalizations, which indicate a smaller space for some than for others, are overcome, bringing more egalitarian contexts within families and impacting on society as a whole.

It is necessary for agents involved in education to be open to continuous reflections on the implications of factors that do not allow subjects to have equal rights, thus providing opportunities for dialogue and encouragement in/by and with more respectful and empathic.

Family cannot be assumed as a closed and unanimous concept that remains inert throughout history, but rather, as susceptible to transformations and capable of generating healthier and more harmonious bonds between the subjects who chose to recognize themselves as participants in the same family nucleus.

This work provided a historical overview of the concept of family, enabling the reflection that we still do not live in a culture of full respect for the various family arrangements, that although the legislation contemplates a growing list of family organizations, we still find resistance to some segments, such as LGBTQI+, non-consanguineous families etc., have in fact their social recognition without prejudice.

The understanding that history undergoes changes continuously can enable an action aimed at breaking up relationships that exclude and segregate. Moving towards a more plural and empathetic society is urgent, which involves the way in which families are seen in the legal sphere and in the relationships that take place between subjects. It is necessary to ask whether an identity mark as strong as the family experiences full freedom today or whether it still finds ties that delimit who is worthy or unworthy.

It is necessary to break with the idea that being in the law is enough for the right to become effective; it is necessary to think of strategies so that social resistance to diversity can be replaced by more respect for individual choices and that subjects can experience one of the marks of their identity with respect and dignity.

Authors' Contributions: Lucifora, C. A.: conception and design, acquisition of data, analysis and interpretation of data, drafting the article, critical review of important intellectual content; Muzzeti, L. R.: conception and design, acquisition of data, analysis and interpretation of data, drafting the article, critical review of important intellectual content; Reina, F. T.: conception and design, acquisition of data, analysis and interpretation of data, drafting the article, critical review of important intellectual content. All authors have read and approved the final version of the manuscript.

Ethics Approval: Not applicable. 
Acknowledgments: Not applicable.

\section{REFERENCES}

Abramowicz, A. (1994) A menina repetente. Campinas, SP: Papirus (Coleção Magistério: Formação e Trabalho Pedagógico).

Ariès, P. (2012 [1981]) História social da criança e da família. Trad. Dora Flaksman. 2. ed. Rio de Janeiro: Livros Técnicos e Científicos.

Biroli, F. (2014) Família: Novos Conceitos. São Paulo: Fundação Perseu Abramo: Partido dos trabalhadores. Bourdieu, P. (2011) Razões práticas: sobre a teoria da ação. Tradução: Maria Corrêa. 11 ed. - Campinas, SP: Papirus. Bourdieu, P.; Passeron, J. (2018) Os herdeiros: os estudantes e a cultura. 2. ed. Florianópolis: Editora UFSC. Tradução Ione Ribeiro Valle, Nilton Valle.

Brasil. Constituição (1988). Constituição da República Federativa do Brasil. Brasília, DF: Centro Gráfico, 1988.

Dessen, M. A; Polonia, A. C. (2005) Em busca de uma compreensão das relações entre família escola. Psicol. esc. educ., Campinas, v. 9, n. 2, p. 303-312, dez.

Giddens, A. (2003) Mundo em descontrole: o que a globalização está fazendo de nós. 3. ed. Rio de Janeiro: Record, 2003.

Goldani, A. M. (1993) As famílias no Brasil contemporâneo e o mito da desestruturação. Caderno Pagu, São Paulo, n. 1.

Hintz, H. C. (2001) Novos tempos, novas famílias? Da modernidade a pós-modernidade. Revista Pensando Famílias, Porto Alegre, n. 3.

Instituto Brasileiro de Geografia e Estatística - IBGE. (2017) Estatísticas do século XX: conceito e definições. Rio de Janeiro: IBGE. Available at: https://seculoxx.ibge.gov.br/populacionais-sociais-politicas-e-culturais/busca-por-palavrachave/populacao/809-familia.html

Kornatzki, L.; Ribeiro, P. R. C. (2019) Seguir o padrão que vinha seguindo - apenas os nomes abreviados. A produção da família no brasil contemporâneo: uma análise de leis e decisões jurídicas. Revista Ibero-Americana de Estudos em Educação, Araraquara, v. 14, n. esp. 2, p. 1304-1320.

Laraia, R. (1999) Cultura: Um conceito Antropológico. 12. ed. Rio de Janeiro: Jorge Zahar. Editores Ltda.

Neto, J. (2017) As novas caras das famílias. Revista Retratos do IBGE 2017. Available at:

https://agenciadenoticias.ibge.gov.br/agencia-noticias/2012-agencia-de-noticias/noticias/19061-as-novas-caras-das$\underline{\text { familias }}$

Noronha, M. M. S.; Parron, S. F. (2020) A evolução do conceito de família. Pitágoras. Available at: http://www.finan.com.br/pitagoras/downloads/numero3/a-evolucao-do-conceito.pdf

Perez, M. C. A. (2010) Família e escola na contemporaneidade: fenômeno social. Revista Ibero-Americana de Estudos em Educação. Araraquara, v. 4, n.3, p. 372-387. Available at:

https://periodicos.fclar.unesp.br/iberoamericana/article/view/2763

Scavone, L. (2001) Maternidade: transformações na família e nas relações de gênero. Interface - Comunicação, Saúde e Educação. Available at: https://www.scielo.br/j/icse/a/NzTkJJrXYGPHDZ3sQRbR9tc/?lang=pt

Singly. F. (2007) Sociologia da família contemporânea. (C. E. Peixoto, Trad.). Rio de Janeiro: Editora FGV.

Received: 31 August 2021 | Accepted: 20 November 2021 | Published: 23 December 2021 